ISSN 1112-9867

http://www.jfas.info

\title{
IMMOBILIZATION OF LEAD IN SHOOTING RANGE SOIL USING BIOCHAR FROM SPENT MUSHROOMSUBSTRATE
}

\author{
S. K.Yong ${ }^{1, *}$, N. A. K. Annuar ${ }^{1}$ and M. J. M. Ariff ${ }^{2}$ \\ ${ }^{1}$ Faculty of Applied Sciences, UniversitiTeknologi MARA, 40450 Shah Alam, Selangor, \\ Malaysia \\ ${ }^{2}$ Centre for Foundation Studies, UniversitiPertahananNasional Malaysia, Sungai Besi Camp, \\ 57000 Kuala Lumpur, Malaysia
}

Published online: 10 November 2017

\begin{abstract}
Spent mushroom substrate (SMS) was pyrolyzed at $450^{\circ} \mathrm{C}$ for 2 hours and characterized using elemental analyzer and Boehm titration. Shooting range soil was incubated with $2.5 \% \mathrm{w} / \mathrm{w}$ and $5.0 \% \mathrm{w} / \mathrm{w}$ of SMSB for four weeks and the soil were characterized on the elemental composition, $\mathrm{pH}$, electric conductivity (EC) and cation exchange capacity (CEC). The mobility of $\mathrm{Pb}$ in the incubated soil were studied using a modified selective sequential extraction (SSE) scheme. Total $\mathrm{Pb}$ in shooting range soil is $29385.5 \mathrm{mg} / \mathrm{kg}$. The texture of shooting range soil is loamy sand with an average soil $\mathrm{pH}$ of 4.69 , EC value $0.17 \mathrm{mS} / \mathrm{mand}$ $\mathrm{CEC}$ value $6.0 \mathrm{mEq} / 100 \mathrm{~g}$. After treatment with $\mathrm{SMSB}$, the soil $\mathrm{pH}$ and $\mathrm{CEC}$ were increased and the concentration of exchangeable $\mathrm{Pb}$ decreased. Conclusively, this study found that there is potential in using SMSB for remediating $\mathrm{Pb}$ contamination in the shooting range soil.
\end{abstract}

Keywords: Spent mushroom compost; charcoal; black carbon; immobilization.

Author Correspondence, e-mail: yongsk@salam.uitm.edu.my

doi: http://dx.doi.org/10.4314/jfas.v9i6s.8 


\section{INTRODUCTION}

Shooting range contains high content of lead $(\mathrm{Pb})$ due to long term deposition of lead shots. Total $\mathrm{Pb}$ concentration in Malaysian shooting range soils may be as high as 17,278 mg/kg [1] Metallic $\mathrm{Pb}$ may be corroded to form hydrocerussite $\left(\mathrm{Pb}_{3}\left(\mathrm{CO}_{3}\right)_{2}(\mathrm{OH})_{2}\right)$, cerussite $\left(\mathrm{PbCO}_{3}\right)$, and massicot $(\mathrm{PbO})$ within a week of atmospheric exposure [2]. Lead is toxic especially for children, as it attacks the developing brain and central nervous system. High level exposure of $\mathrm{Pb}$ through inhalation or ingestion may cause coma, convulsions and even death to human. Effective removal of soil $\mathrm{Pb}$ may be achieve by the costly soil washing technique. Alternatively, leaching of $\mathrm{Pb}$ from shooting range soil may be achieved by immobilization technique, using cheap liming minerals such as ground magnesium limestone, basalt or spent mushroom substrate (SMS).

Spent mushroom substrate is a waste biomass from the mushroom cultivation industry. About $5 \mathrm{~kg}$ of SMS is produced per $\mathrm{kg}$ production of mushroom and most SMS is reprocessed as agricultural compost or disposed by incineration and landfilling [3]. In fact, SMS have been studied for decontamination of acid mine drainage [4]. The abundance and high alkalinity of SMS makes it an ideal material for immobilization of $\mathrm{Pb}$ in shooting range soil. Spent mushroom compost contain carbon-rich sawdust, and is recommended as feedstock for biochar production [5]. In fact, SMS has been converted to biochar for removal of ammonia-N from the aqueous system [6]. Spent mushroom compost may be pyrolyzed at a low oxygen environment to produce a relatively stable, carbon-rich material called biochar, minimizing microbial degradation that releases pollutants from SMS into the environment. To the best of our knowledge, the potential of SMSB for immobilization of soil $\mathrm{Pb}$ has not been investigated. This study aims to (i) synthesize and characterize SMSB; (ii) elucidate the immobilization of $\mathrm{Pb}$ in shooting range soil by SMSB.

\section{RESULTS AND DISCUSSION}

\subsection{Physico-chemical Properties for SMS and SMSB}

The yield of SMSB from pyrolysis of SMS was 35\% w/w. Similar to other biochar, SMSB has a higher pH (i.e., 9.73) compare to SMS feedstock (i.e., 7.5), possible due to the presence of alkaline minerals in the burnt ash. The CEC value for SMSB (i.e., $9.5 \mathrm{mEq} / 100 \mathrm{~g}$ ) is slightly 
higher than those of shooting range soil (i.e., $6.0 \mathrm{mEq} / 100 \mathrm{~g}$ ). Ash content for SMS and SMSB are similar (i.e., $27.7 \% \mathrm{w} / \mathrm{w}$ and $27.8 \% \mathrm{w} / \mathrm{w}$ respectively) and is slightly higher than that of rubber wood sawdust $(22.7 \% \mathrm{w} / \mathrm{w})$ [7], due to the addition of lime $\left(\mathrm{CaCO}_{3}\right)$ during the preparation of SMS [8].

The elemental composition ( $\% \mathrm{w} / \mathrm{w})$ for SMS, SMSB and HCl-SMSB are shown in Table 1. Pyrolysis process on has increased percentage of $\mathrm{C}$ and $\mathrm{H}$ contents, and decreased that of $\mathrm{O}$ and $\mathrm{N}$ for SMSB. The H/C molar ratio for the SMSB (i.e., 0.3) was lower than that of SMS (1.6), indicating that SMSB is more stable than SMS [9]. Treatment of $1.0 \mathrm{M} \mathrm{HCl}$ has removed $21.3 \% \mathrm{w} / \mathrm{w}$ of soluble fraction from the ash from SMSB, most of which are $\mathrm{Ca}(10 \%$ $\mathrm{w} / \mathrm{w})$ and $\mathrm{K}(0.4 \% \mathrm{w} / \mathrm{w})$. However, heavy metals such as $\mathrm{Cr}, \mathrm{Pb}$ and $\mathrm{Zn}$ remains unchanged. This indicates that the toxic heavy metals in SMSB are stable and are not soluble in water. The acidic functional groups on the surface of the HCl-treated SMSB consists of primarily carboxylic $(0.3 \mathrm{mmol} / \mathrm{g})$ and phenolic groups $(0.5 \mathrm{mmol} / \mathrm{g})$. The amount for basic functional groups for SMSB was $0.2 \mathrm{mmol} / \mathrm{g}$.

Table 1.Elemental composition (\% w/w) for SMS, SMSB, and HCl-treated SMSB

\begin{tabular}{cccc}
\hline Elements & SMS & SMSB & HCl-Treated SMSB \\
\hline $\mathrm{C}$ & 44.0 & 53.3 & 72.8 \\
$\mathrm{O}$ & 21.4 & 11.1 & 18.6 \\
$\mathrm{H}$ & 5.8 & 2.6 & 2.0 \\
$\mathrm{~N}$ & 1.0 & 0 & 0.1 \\
$\mathrm{~S}$ & 0.1 & 0 & 0 \\
$\mathrm{Ca}$ & & 12.8 & 2.8 \\
$\mathrm{Cr}$ & & 0.1 & 0.1 \\
$\mathrm{~K}$ & & 0.5 & 0.1 \\
$\mathrm{Mg}$ & & 0.8 & 0.8 \\
$\mathrm{~Pb}$ & & 0.2 & 0.2 \\
$\mathrm{Zn}$ & & 0.1 & 0.1 \\
\hline
\end{tabular}

\subsection{Physico-chemical Properties for Shooting Range Soil}

Table 2 shows the physico-chemical properties of shooting range soil. The soil type is of 
loamy sand, which consists of $73 \%, 15 \%$ and $12 \%$ of sand, silt and clay respectively. The soil $\mathrm{pH}$ is 4.69 and is classified as very strongly acidic [10]. Shooting range soil has a very low organic content, as indicated by the low $\operatorname{SOM}(3.8 \% \mathrm{w} / \mathrm{w})$ and SOC contents $(2.2 \% \mathrm{w} / \mathrm{w})$. The total metal contents of shooting range soil is shown in Table 3. Total soil $\mathrm{Pb}$ content is $29385.5 \mathrm{mg} / \mathrm{kg}$, and is significantly higher than the Malaysian recommended site screening levels for soil $\mathrm{Pb}$ (i.e., $800 \mathrm{mg} / \mathrm{kg})$ [11]. Low soil CEC value $(6.0 \mathrm{mEq} / 100 \mathrm{~g})$ conforms to those of a loamy sand soil. The combination of high soil $\mathrm{Pb}$, low soil $\mathrm{pH}$ and $\mathrm{CEC}$ may lead to leaching of $\mathrm{Pb}$ ions into water resources.

Table 2.Physico-chemical properties for shooting range soil

\begin{tabular}{cc}
\hline Soil Parameters & Average Value \\
\hline $\mathrm{pH}$ & $4.69 \pm 0.15$ \\
$\mathrm{EC}(\mathrm{mS} / \mathrm{m})$ & 0.17 \\
Moisture $(\% \mathrm{w} / \mathrm{w})$ & $13 \pm 2.49$ \\
$\mathrm{CEC}(\mathrm{mEq} / 100 \mathrm{~g})$ & 6.0 \\
$\% \mathrm{Sand}$ & 73 \\
$\% \mathrm{Silt}$ & 15 \\
$\% \mathrm{Clay}$ & 12 \\
SOM $(\% \mathrm{w} / \mathrm{w})$ & $3.8 \pm 0.94$ \\
SOC $(\% \mathrm{w} / \mathrm{w})$ & $2.2 \pm 0.55$ \\
\hline
\end{tabular}


Table 3. Total metal $(\mathrm{mg} / \mathrm{kg})$ of shooting range soil

\begin{tabular}{ll}
\hline Metal & Total Content $(\mathbf{m g} / \mathbf{k g})$ \\
\hline $\mathrm{Pb}$ & $29385.5 \pm 3308.1$ \\
$\mathrm{Fe}$ & $11906.7 \pm 167.4$ \\
$\mathrm{Cu}$ & $7109.4 \pm 8623.5$ \\
$\mathrm{~K}$ & $3778.5 \pm 1006.8$ \\
$\mathrm{Zn}$ & $1054.8 \pm 1120$ \\
$\mathrm{Mg}$ & $536.4 \pm 66.6$ \\
$\mathrm{Ca}$ & $305.7 \pm 1.3$ \\
$\mathrm{Mn}$ & $189.9 \pm 2.6$ \\
$\mathrm{Na}$ & $134.3 \pm 31.7$ \\
\hline
\end{tabular}

\subsection{Soil Incubation and Characterization}

The images of the texture of shooting range soils after incubation with $5 \% \mathrm{w} / \mathrm{w}$ SMS and $5 \%$ w/w SMSB are shown in Fig.1. The presence of SMS and SMSB has cause aggregation of fine soil particles, forming course granular, and friable soil aggregates. This is due to the increasing soil organic matter, due to the addition of SMS and SMSB. The presence of SMSB has given a darker appearance to the soil colourFig.1. (iii).

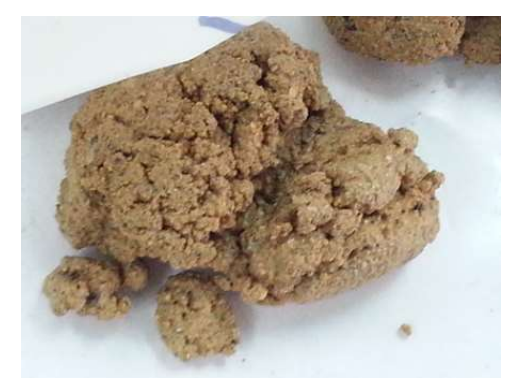

(i)

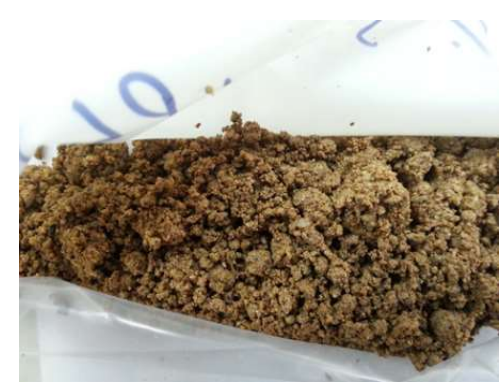

(ii)

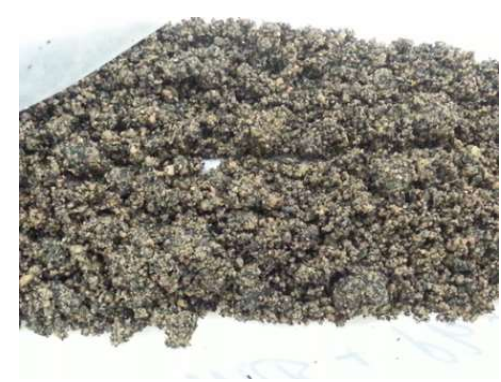

(iii)

Fig.1. Shooting range soils (i), incubated with (ii) $5 \% \mathrm{w} / \mathrm{w}$ SMS; and (iii) 5\% w/w SMSB The $\mathrm{pH}$ and CEC values for incubated soil are shown in Table 4. The increasing application of SMSB has proportionally increased the $\mathrm{pH}$ value of shooting range soil. Incubation with $2.5 \%$ $\mathrm{w} / \mathrm{w}$ and $5.0 \% \mathrm{w} / \mathrm{w}$ SMSB has increased the $\mathrm{pH}$ of shooting range soil from 4.69 to 5.56 and 7.73 respectively. The alkaline minerals in the ash of the SMSB has neutralized the acidity in shooting range soil. The CEC values for the incubated soil samples were also increased 
slightly from 6.0 to 6.7 and 7.0. The introduction of porous and negative-charged surface of SMSB may have increased the CEC values of shooting range soil [12]. Furthermore, the increased soil $\mathrm{pH}$ after incubation with SMSB may also induced deprotonation of functional groups on the surface of soil particles and organic matter, and contributed to higher CEC values for the SMSB-incubated soil, and providing more available binding sites for retention of $\mathrm{Pb}$ ions.

Table 4.Physico-chemical properties of SMSB-incubated shooting range soil at $0.0,2.5,5.0 \%$ $\mathrm{w} / \mathrm{w}$ of application rate

\begin{tabular}{llll}
\hline \multirow{2}{*}{ Property } & \multicolumn{3}{c}{ Application Rate (\% w/w) } \\
& $\mathbf{0 . 0}$ & $\mathbf{2 . 5}$ & $\mathbf{5 . 0}$ \\
\hline $\mathrm{pH}$ & 4.69 & 5.56 & 7.73 \\
$\mathrm{CEC}, \mathrm{mEq} / 100 \mathrm{~g}$ & 6.0 & 6.7 & 7.0 \\
\hline
\end{tabular}

\subsection{Modified Selective Sequential Extraction}

Table 5 shows the distribution of $\mathrm{Pb}(\% \mathrm{w} / \mathrm{w})$ in the five fractions of the SSE experiment. The exchangeable $\mathrm{Pb}$ for shooting range soil (CTR) was $0.6 \%$. Incubation with 5\% w/w SMS and $5 \% \mathrm{w} / \mathrm{w}$ SMSB have reduced the exchangeable $\mathrm{Pb}$ to $0.4 \% \mathrm{w} / \mathrm{w}$ and $0.0 \% \mathrm{w} / \mathrm{w}$ respectively. Shooting range soils that were incubated with SMS and SMSB have significantly higher carbonate-bound $\mathrm{Pb}$ fraction, increased from $4.9 \% \mathrm{w} / \mathrm{w}(\mathrm{CTR})$ to $71.5 \% \mathrm{w} / \mathrm{w}$ and $77.1 \% \mathrm{w} / \mathrm{w}$ respectively. Conversely, incubation with SMS and SMSB decreased the organic bound $\mathrm{Pb}$ for CTR $(77.4 \% \mathrm{w} / \mathrm{w})$ to $9.6 \% \mathrm{w} / \mathrm{w}$ and $6.4 \% \mathrm{w} / \mathrm{w}$ respectively. These changes may indicate: (1) precipitation of available $\mathrm{Pb}$ ions to $\mathrm{Pb}$ carbonate from the increase of soil $\mathrm{pH}$; (2) mobilization of organic bound $\mathrm{Pb}$ (i.e., Pbhumate) and transformation to carbonate bound $\mathrm{Pb}$ due to high soil $\mathrm{pH}$. Most of the $\mathrm{Pb}$ in shooting range soil was bound to the existing organic matter in the soil. When both SMS and SMSB were incubated, shooting range soils were introduced with the alkaline $\mathrm{Ca}$ minerals (i.e., calcium carbonate and calcium oxide). The increase of soil $\mathrm{pH}$ may have hydrolyzed existing soil carbon to soluble fraction, but the presence of hydroxide ions in the alkaline soil may have formed $\mathrm{Pb}$ hydroxide, and eventually to $\mathrm{Pb}$ carbonate $[13]$. 
Table 5. Distribution of $\mathrm{Pb}(\% \mathrm{w} / \mathrm{w})$ in the selective sequential extraction (SSE) fractions (exchangeable, carbonate, Fe/Mn oxide, organic and residual) for shooting range soil (CTR) and incubated soils (5\% SMS and 5\% SMSB)

\begin{tabular}{lccc}
\hline \multirow{2}{*}{ SSE Fractions } & \multicolumn{3}{c}{ Pb (\% w/w) } \\
& $\mathbf{5 \%}$ SMS & $\mathbf{5 \%}$ SMSB & CTR \\
\hline Exchangeable & 0.4 & 0.0 & 0.6 \\
Carbonate-bound & 71.5 & 77.1 & 4.9 \\
Fe/Mn oxide-bound & 15.7 & 13.3 & 12.4 \\
Organic-bound & 9.6 & 6.4 & 77.4 \\
Residual & 2.7 & 3.1 & 4.7 \\
\hline
\end{tabular}

\section{EXPERIMENTAL}

\subsection{Sampling and Preparation of SMSB}

Spent mushroom substrate (SMS) were collected from an oyster mushroom (i.e., Pleurotusostreatus) farm at Gerisek, Johor (GPS coordinate: 2.233387, 102.700237). The as-received SMS was autoclaved, oven-dried at $60^{\circ} \mathrm{C}$ for 5 days and sieved using a 2-mm mesh screen. Spent mushroom substrate biochar (SMSB) was prepared by pyrolyzing SMS in a furnace at $450^{\circ} \mathrm{C}$ for $2 \mathrm{~h}$ under nitrogen atmosphere Fig. 1. Hot SMSB was quenched and rinsed thoroughly with deionized (DI) water, oven-dried at $100^{\circ} \mathrm{C}$ for 24 hours and sieved to particle size of $150 \mu \mathrm{m}$. The yield of SMSB (\% w/w) was calculated with Equation (1):

$$
\% \text { Yield }=\frac{W_{c}}{W_{d s}} \times 100
$$

whereWc and Wds are the weights for SMSB (g) and dried SMS (g) respectively. 


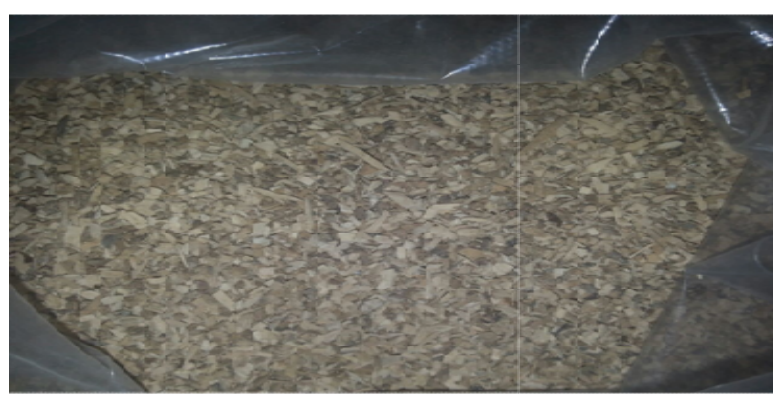

\section{SMS}
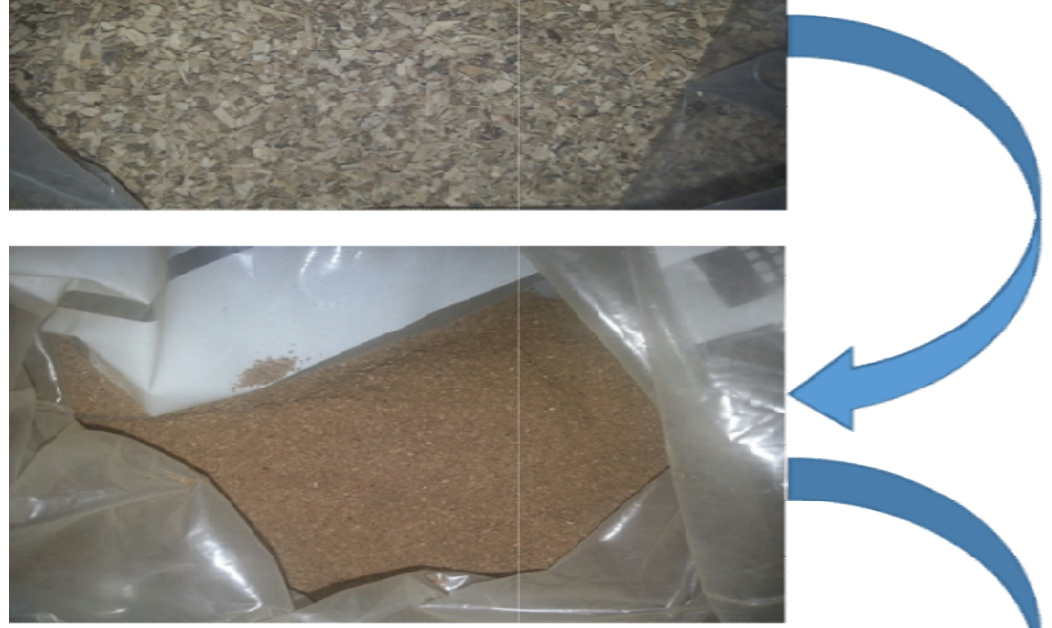

Pulverized

\& sieved

to $<2 \mathrm{~mm}$
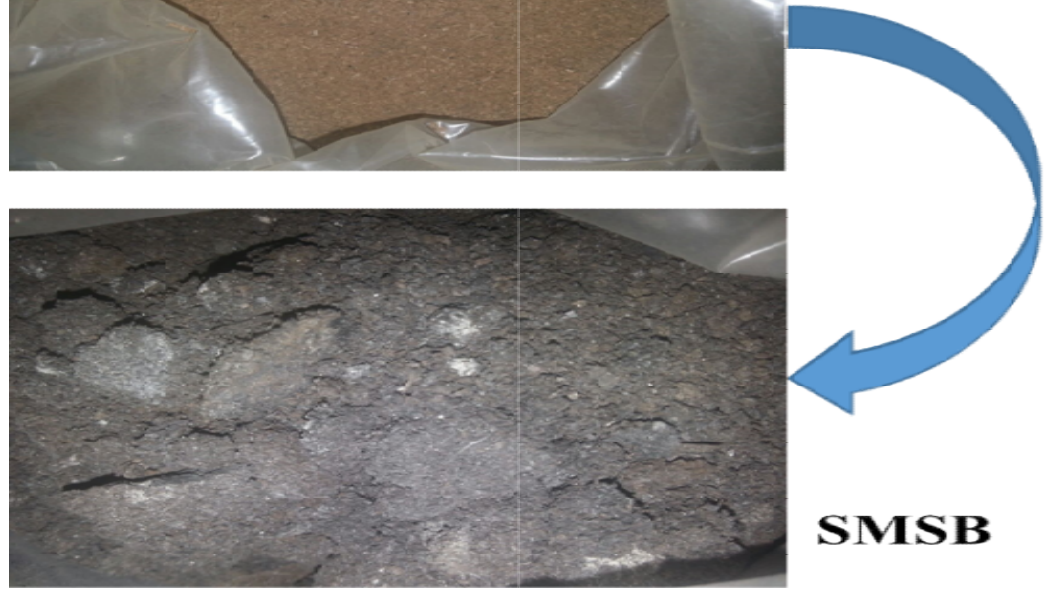

Pyrolysis at

$450^{\circ} \mathrm{C}$ for $2 \mathrm{~h}$

at nitrogen

atmosphere

Fig.1.Preparation of SMSB from SMS

\subsection{Sampling and Preparation of Shooting Range Soil}

Soil samples were collected at Royal Malaysian Police Forces Shooting Range at Kuala KubuBharu, Selangor, Malaysia (GPS coordinates: 3.575858, 101.667350). The soil samples were collected at ten sampling points using an Auger sampler at a depth of $30 \mathrm{~cm}$ from the soil surface. The soil sample was air-dried for 3 days and sieved with a 2-mm mesh screen. Lead shots were removed manually and the air-dried soil samples were stored in plastic zip-lock bag.

\subsection{Physico-Chemical Characterization for SMS, SMSB and Shooting Range Soil}

The $\mathrm{pH}$ and $\mathrm{EC}$ values for shooting range soil and SMSB were determined using a calibrated $\mathrm{pH} / \mathrm{EC}$ meter. $\mathrm{pH}$ values were measured on DI water slurry at 1:1 solid-solution ratio, while EC values were measured from the filtrates of DI water slurry at 1:5 solid-solution ratio. Soil particle distribution was determined with the hydrometer method [14]. The cation exchange capacity (CEC) for shooting range soil and SMSB was determined using USEPA Method 
9081 [15]. Soil organic matter (SOM) was determined using the loss-on-ignition (LOI) method [16], and the soil organic carbon (SOC) was calculated using Equation (2)[17]. Inorganic carbon (IC) content for shooting range soil were determined from a DI water extract (soil/solution ratio: 1:2) and analyzed with a TOC analyzer (Shimadzu TOC-V/TN). Inorganic ash component in SMSB was eliminated by agitation with $0.05 \mathrm{M} \mathrm{HCl}$, DI water, and $0.05 \mathrm{M}$ $\mathrm{CaCl}_{2}$ solution. The HCl-treated SMSB was oven-dried at $100^{\circ} \mathrm{C}$ for $12 \mathrm{~h}$ and the surface functional groups for SMSB was determined using Boehm titration method [18]. Air-dried soil samples and SMSB were digested using aqua-regia[19], filtered and analyzed with inductively coupled plasma optical emission spectroscopy (ICP-OES) (Perkin Elmer DV7300), and the total metal content $(\mathrm{mg} / \mathrm{kg})$ in soil samples were calculated according to Equation (3).

$$
S O C=\frac{S O M}{1.72}
$$

Total metal content $=[$ metal $] \times \mathrm{V} / \mathrm{m}_{\text {soil }}$

where [metal] is the concentration of metal ion in digested solution, $\mathrm{V}$ is the volume of digested solution and $\mathrm{m}_{\text {soil }}$ is the mass of soil sample $(\mathrm{kg})$.

\subsection{Soil Incubation and Characterization}

Shooting range soil was mixed with SMSB at two application rates of $2.5 \%$ and $5.0 \% \mathrm{w} / \mathrm{w}$. The shooting soils were again incubated with SMS and SMSB at 5\% w/w application rate and were further analyzed using the modified SSE scheme. All soil samples were incubated for four weeks at room temperature $\left(25^{\circ} \mathrm{C}\right)$. Soil moisture contents were maintained at field capacity by frequent watering using DI water. The $\mathrm{pH}$ and $\mathrm{CEC}$ values of the incubated soils were determined as described earlier.

\subsection{Modified Selective Sequential Extraction}

A modified SSE scheme that consist of 5 fractions (i.e., exchangeable, carbonate-bound, Fe/Mn oxides-bound, organic-bound and residual) (Table 6) was adopted [20]. One gram of the incubated soil sample was extracted in a $50 \mathrm{~mL}$ centrifuge tube and the soil-solution mixture was agitated using an end-over-end shaker. Then, the mixture was centrifuged at 15,000 rpm for $10 \mathrm{~min}$, decanted and the residue soil was washed twice with $5 \mathrm{~mL}$ of DI water. The supernatants were collected from each steps of extraction and was diluted to $50 \mathrm{~mL}$ using DI 
water. The $\mathrm{Pb}$ concentration of the extracts was analyzed with ICP-OES. The percentage of $\mathrm{Pb}$ in each fractions $\left(\mathrm{Pb}_{\mathrm{f}}\right)$ were calculated using Equation (4).

$$
P b_{f}(\% w / w)=\frac{[P b]_{f} \times V_{f}}{m_{S_{\text {Sol }} P b}} \times 100
$$

where $[\mathrm{Pb}]_{\mathrm{f}}$ is the concentration of $\mathrm{Pb}(\mathrm{mg} / \mathrm{L}), \mathrm{V}_{\mathrm{f}}$ is the volume of fraction $(\mathrm{L})$ and $\mathrm{m}_{\text {soil_ } \mathrm{Pb}}$ is the total mass of $\mathrm{Pb}$ is the shooting range soil $(\mathrm{mg})$.

Table 6. Reagents and conditions for the modified Selective Sequential Extraction (SSE)

\begin{tabular}{|c|c|c|c|}
\hline Step & Fraction & Reagent & Agitation Time/Temperature \\
\hline 1 & Exchangeable & $8 \mathrm{~mL}$ of $1.0 \mathrm{M} \mathrm{MgCl}_{2} \cdot 6 \mathrm{H}_{2} \mathrm{O}(\mathrm{pH} 7)$ & $1 \mathrm{~h}$ at $25^{\circ} \mathrm{C}$ \\
\hline 2 & Carbonate-bound & $8 \mathrm{~mL}$ of $1.0 \mathrm{M} \mathrm{CH}_{3} \mathrm{COONa}(\mathrm{pH} 5)$ & $3 \mathrm{~h}$ at $25^{\circ} \mathrm{C}$ \\
\hline \multirow[t]{2}{*}{3} & Fe/Mn oxides-bound & $20 \mathrm{~mL}$ of $0.04 \mathrm{M} \mathrm{NH}_{2} \mathrm{OH} . \mathrm{HCl}$ in & Occasional agitation for $6 \mathrm{~h}$ at \\
\hline & & $25 \%(\mathrm{v} / \mathrm{v}) \mathrm{CH}_{3} \mathrm{COOH}$ & $95^{\circ} \mathrm{C}$ \\
\hline \multirow[t]{5}{*}{4} & Organic-bound & $5.0 \mathrm{~mL}$ of $30 \% \mathrm{v} / \mathrm{v} \mathrm{H}_{2} \mathrm{O}_{2}(\mathrm{pH} 2)$ & $2 \mathrm{~h}$ at $85^{\circ} \mathrm{C}$ \\
\hline & & $3.0 \mathrm{~mL}$ of $0.02 \mathrm{M} \mathrm{HNO}_{3}$ & \\
\hline & & $3.0 \mathrm{~mL}$ of $30 \% \mathrm{v} / \mathrm{v} \mathrm{H}_{2} \mathrm{O}_{2}(\mathrm{pH} 2)$ & $2 \mathrm{~h}$ at $85^{\circ} \mathrm{C}$ \\
\hline & & cool, add $5.0 \mathrm{~mL}$ of $3.2 \mathrm{M}$ & \\
\hline & & $\mathrm{CH}_{3} \mathrm{COONH}_{4}$ in $20 \% \mathrm{v} / \mathrm{v} \mathrm{HNO}_{3}$ & $0.5 \mathrm{~h}$ at $25^{\circ} \mathrm{C}$ \\
\hline \multirow[t]{2}{*}{5} & Residual & $9 \mathrm{~mL} \mathrm{37 \%} \mathrm{HCl \&} 3 \mathrm{~mL} \mathrm{HNO}_{3}$ & Microwave digestion EPA \\
\hline & & & Method 3051 [19] \\
\hline
\end{tabular}

\section{CONCLUSION}

Based on the result obtained in this study, the properties of soil were improved by application of SMS and SMSB. The increased of $\mathrm{pH}$ and CEC of the SMSB-incubated soil may help reduce leaching of $\mathrm{Pb}$ from soil. In the $\mathrm{SSE}$ experiment, the significant reduction of exchangeable $\mathrm{Pb}$ upon treatment with SMSB shows its potential as amendment for immobilization of $\mathrm{Pb}$ in shooting range soil. Based the incubation experiment setup, the presence carbon in the SMSB-incubated soil did not show immediate interactions with $\mathrm{Pb}$. Further studies on the long-term SMSB incubation on soil $\mathrm{Pb}$ speciation is warranted to understand SMSB's overall $\mathrm{Pb}$ immobilization mechanism. 


\section{ACKNOWLEDGEMENTS}

The authors would like to thank the Ministry of Higher Education for financially supporting this research project through the Fundamental Research Grant Scheme (FRGS) [600-RMI/FRGS 5/3 (0128/2016)], the UniversitiTeknologi MARA for providing research facility,The Royal Malaysian Police Forces for assistance in collecting shooting range soil samples and C \& C Mushroom Malaysia for supplying SMS.

\section{REFERENCES}

[1] Yong S K, Mohd Z S N, Mad A M J. Effects of rain pH, soil organic matter, cation exchange capacity and total lead content in shooting range soil on the concentration of lead in leachate. Malaysian Journal of Analytical Sciences, 2016, 20(5):1066-1072

[2] Hardison Jr D W, Ma L Q, Luongo T, Harris W G. Lead contamination in shooting range soils from abrasion of lead bullets and subsequent weathering. Science of the Total Environment, 2004, 328(1-3):175-183

[3] Phan C W, Sabaratnam V. Potential uses of spent mushroom substrate and its associated lignocellulosic enzymes. Applied Microbiology and Biotechnology, 2012, 96(4):863-873

[4] Finney K N, Ryu C, Sharifi V N, Swithenbank J. The reuse of spent mushroom compost and coal tailings for energy recovery: Comparison of thermal treatment technologies. Bioresource Technology, 2009, 100(1):310-315

[5] Liu X, Zhang Y, Li Z, Feng R, Zhang Y. Characterization of corncob-derived biochar and pyrolysis kinetics in comparison with corn stalk and sawdust. Bioresource Technology, 2014, 170:76-82

[6] Liu N, Zhou C J, Fu S F, Ashraf M I, Zhao E F, Shi H, Han X R, Hong Z B. Study on characteristics of ammonium nitrogen adsorption by biochar prepared in different temperature. Advanced Materials Research, 2013, 724:452-456

[7] Ghani W A W A K, Mohd A, da Silva G, Bachmann R T, Taufiq Y Y H, Rashid U, Al-Muhtaseb A A H. Biochar production from waste rubber-wood-sawdust and its potential use in $\mathrm{C}$ sequestration: Chemical and physical characterization. Industrial Crops and Products, 2013, 44:18-24

[8] Mat A M Z, Mohd Y S, Harun A. Daya maju perusahaan cendawan tiram di Semenanjung 
Malaysia. Economic and Technology Management Review, 2013, 8:13-25

[9] Budai A, Zimmerman A, Cowie A, Webber J, Singh B, Glaser B, Masiello C, Andersson D, Shields F, Lehmann J. Biochar carbon stability test method: An assessment of methods to determine biochar carbon stability. Carbon Methodology, IBI Document, 2013

[10] National Soil Survey Center, Soil Quality Institute, National Soil Tilth Laboratory Soil Quality Indicators: pH. Soil Quality Information Sheet, 1998

[11] Department of Environment (DOE). Contaminated land management and control guidelines, in no. 3: Remediation of contaminated sites.Putrajaya: Ministry of Natural Resource and Environment, Malaysia, 2009

[12] Nigussie A, Kissi E, Misganaw M, Ambaw G. Effect of biochar application on soil properties and nutrient uptake of lettuces (Lactuca sativa) grown in chromium polluted soils. American-Eurasian Journal of Agriculture and Environmental Science, 2012, 12(3):369-376

[13] Godelitsas A, Astilleros J M, Hallam K, Harissopoulos S, Putnis A. Interaction of calcium carbonates with lead in aqueous solutions. Environmental Science and Technology, 2003, 37(15):3351-3360

[14] Kaur A, Fanourakis G. Effect of hydrometer type on particle size distribution of fine grained soil. In 1st Southern African Geotechnical Conference, 2016, pp. 1-8

[15] Jaremko D, Kalembasa D. A comparison of methods for the determination of cation exchange capacity of soils/Porównanie metod oznaczania pojemności wymiany kationów i sumy kationów wymiennych w glebach. Ecological Chemistry and Engineering S, 2014, 21(3):487-498

[16] Fernández-Romero M, Clark J, Collins C, Parras-Alcántara L, Lozano-García B. Evaluation of optical techniques for characterising soil organic matter quality in agricultural soils. Soil and Tillage Research, 2016, 155:450-460

[17] Zheng X, Fan J, Xu L, Zhou J. Effects of combined application of biogas slurry and chemical fertilizer on soil aggregation and $\mathrm{C} / \mathrm{N}$ distribution in an ultisol. PloS One, 2017, 12(1):1-16

[18] Boehm H P, Chapter 13-Surface Chemical characterization of carbons from adsorption studies. In E. J. Bottani, \& J. M. D. Tascón (Eds.), Adsorption by carbons.Amsterdam: Elsevier, 2008, pp. 301-327 
[19] Link D D, Walter P J, Kingston H. Development and validation of the new EPA microwave-assisted leach method 3051A. Environmental Science and Technology, 1998, 32(22):3628-3632

[20] O'Sullivan A D, Moran B M, Otte M L. Accumulation and fate of contaminants ( $\mathrm{Zn}, \mathrm{Pb}$, Fe and S) in Substrates of wetlands constructed for treating mine wastewater. Water, Air, and Soil Pollution, 2004, 157(1):345-364

\section{How to cite this article:}

Yong S K, Khairoll Annuar N A, and Jaafar Mad Ariff M. Immobilization of Lead in Shooting Range Soil Using Biochar From Spent MushroomSubstrate. J. Fundam. Appl. Sci., 2017, 9(6S), 89-101. 